\title{
Research Paper: \\ Impact of Turmeric Curcuma longa on the Body Weight and Liver Function of Japanese Quails Exposed to Dietary Aflatoxins
}

\author{
Omid Karimi $^{*}$ Q, Mohammad Reza Mofidi ${ }^{2}$, Mohammad Sadegh Saeidabadi ${ }^{3}$
}

1. Department of Animal Viral Diseases Research, Razi Vaccine and Serum Research Institute, Agricultural Research, Education and Extension Organization, Karaj, Iran.

2. Department of Animal Science Research, Yazd Agricultural and Natural Resources Research and Education Center, Agricultural Research, Education and Extension Organization, Yazd, Iran.

3. Department of Poultry Viral Diseases Research, Razi Vaccine and Serum Research Institute, Agricultural Research, Education and Extension Organization, Karaj, Iran.

\begin{tabular}{|c|c|}
\hline $\begin{array}{l}\text { Use vourdevice to scan } \\
\text { and read the article online }\end{array}$ & How to cite this paper Karimi O, Mofidi MR, Saeidabadi MS. Impact of Turmeric Curcuma longa on the Body Weight and \\
\hline 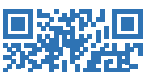 & $\begin{array}{l}\text { Liver Function of Japanese Quails Exposed to Dietary Aflatoxins. Iranian Journal of Toxicology. 2020; 14(2):115-122. http:// } \\
\text { dx.doi.org/10.32598/ijt.14.2.412 }\end{array}$ \\
\hline 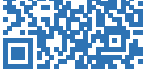 & d ci/ http://dx.doi.org/10.32598/ijt.14.2.412 \\
\hline
\end{tabular}

\section{(O)}

Article info:

Received: 26 Nov 2019

Accepted: 13 Mar 2020

Online Published: 01 Apr 2020

* Corresponding author:

Omid Karimi, PhD

Address: Department of Animal Viral Diseases Research, Razi Vaccine and Serum Research Institute, Agricultural Research, Education and Extension Organization, Karaj, Iran

E-mail: karimi112@gmail.com

\section{A B S T R ACT}

Background: The contamination of poultry feed with Aflatoxins (AF) is important in terms of economic damage to the poultry industry and public health. The objective of this study was to assess the impact of Turmeric Powder (TP), containing 2.96\% of Total Curcuminoids (TCM) on reducing the adverse effects of dietary AF in Japanese quails.

Methods: 180 male Japanese quails aged 22-55 days were divided into six groups, and were fed basic diet (group 1, controls), or basic diet contaminated with $4 \mathrm{mg} / \mathrm{kg} \mathrm{AF}$ and $/$ or TP doses as follows: $3 \mathrm{~g} / \mathrm{kg}$ TP (group 2), $5 \mathrm{~g} / \mathrm{kg}$ TP (group 3), $4 \mathrm{mg} / \mathrm{kg} \mathrm{AF}$ (group 4), $4 \mathrm{mg} / \mathrm{kg} \mathrm{AF}$ and $3 \mathrm{~g} / \mathrm{kg}$ TP (group 5) or $4 \mathrm{mg} / \mathrm{kg} \mathrm{AF}$ and $5 \mathrm{~g} / \mathrm{kg} \mathrm{TP}$ (group 6).

Results: Adding TP to the quails diet that contained AF improved the liver antioxidant status, reduced Malondialdehyde (MDA) concentration, increased the serum SOD and CAT enzyme levels and improved the total antioxidant capacity $(\mathrm{P}<0.05)$. The addition of TP significantly reduced the adverse effects of $\mathrm{AF}$ on body weight loss, relative liver weight gain, decreased serum total protein, and increased the AST, ALT and ALP enzyme activities. It also reduced the severity of liver histological pathologies, such as fatty changes, biliary duct proliferation, periportal fibrosis, hyperemia, and leukocyte infiltration.

Conclusion: The effect of TP on reducing the adverse effects of dietary AF may be attributed to its antioxidant properties. The AF-contaminated diet containing $5 \mathrm{~g} / \mathrm{kg} \mathrm{TP}(148 \mathrm{mg} / \mathrm{kg}$ TCM) was more effective in reducing the AF complications in the quails compared to $3 \mathrm{~g} / \mathrm{kg}$ of TP $(88.8 \mathrm{mg} / \mathrm{kg} \mathrm{TCM})$

Keywords: Aflatoxins; Japanese quails; Curcuma longa; Serum liver enzymes; Histopathologic changes

\section{Introduction}

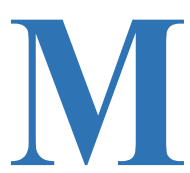

ycotoxins, produced by secondary fungal metabolites, have negative effects on human and animal health. Aflatoxins (AF) are the major my- cotoxins commonly found in the poultry feeds, such as cereal grains and soybean meals. The AF toxins are mainly produced by the two species of Aspergillus flavus and Aspergillus parasiticus. Chemically, AF are furanocoumarin compounds, including AF-B1, -B2, -G1, and -G2. Among these, AFB1 has the most hepa- 
totoxic, teratogenic and carcinogenic effects on both humans and animals [1-3].

Contamination with AF is a major problem in the poultry industry, which increases the mortality, reduces production, and has adverse effects on the public health. The toxins in poultry reduce disease resistance and render vaccination programs unsuccessful. The sensitivity to AF varies considerably among different poultry species. The susceptibility of Japanese quails to AF is higher than those seen in chickens [3-5]. Being primarily hepatotoxins, AF are bio-transformed in the liver by cytochrome P450 enzymes and converted to a highly active compound known as AFB1 exo-8,9-epoxide. The highly reactive form of epoxide is capable of adducting with vital macromolecules of RNA, DNA, and proteins, and is responsible for the toxicity of AFB1 [4-6].

Currently, medicinal plants are used to reduce the adverse effects of AF. Among other medicinal plants, turmeric has gained much attention $[3,7,8]$. The most commonly used edible and medicinal part of turmeric is its dried and powdered roots. The healing properties and yellowish color of turmeric are related to its curcum compounds with synergistic effects. Curcumin is a natural polyphenolic compound, with antioxidant, antiinflammatory, and anti-cancer properties. It also offers detoxifying effects and protects against cellular damages caused by radiation and chemotherapy [8-10].

Previous studies have shown that curcumin can reduce the adverse effects of AF in several animal species. The positive effects of Turmeric Powder (TP) on poultry have been reported, including improvement in blood and biochemical markers, increased immune response and decreased heat stress [7-9, 11, 12]. Its other beneficial properties include lowering the deleterious effects of AF, enhancing antioxidant capacity and inhibiting the harmful intestinal bacteria [7-9, 11, 12]. The aim of this study was to investigate the effect of TP, containing a total of $2.96 \%$ curcuminoids (TCM) in modulating the complications of AF experimentally added to the feed in male Japanese quails.

\section{Materials and Methods}

Preparation and Measurement of AF Activity: The required toxin was prepared with rice using Aspergillus parasiticus [13]. The determination of AF concentration was achieved by High Performance Liquid Chromatography (HPLC) based on the Standard 6872 of the Institute of Standard and Industrial Research of Iran [14]. Rice powder containing four natural AF species (B1, B2,
G1 \& G2) was approved at percentages of 82.6, 8.9, 7.6 and 0.9 , respectively. The rice powder was contaminated with $136 \mathrm{mg} / \mathrm{kg}$ total AF. The contaminated rice powder was kept in a refrigerator. The contamination of the basic diet with AF was trace $(2 \mu \mathrm{g} / \mathrm{kg})$.

Preparation of TP and Measurement of TCM: The turmeric roots were washed, dried and powdered after being identified and approved by experts in medicinal plants. The TP was kept in a refrigerator to prevent moisture absorption and was gradually added to the birds' diet. The quantification of curcuminoids was made using the method of Jayaprakasha et al. [10]. The standard TCM content in the TP were $2.96 \%$. The TCM contents in 3 and 5 grams of TP were 88.8 and $148 \mathrm{mg} / \mathrm{kg}$, respectively.

Study Plan and Birds' Grouping: Twenty two dayold male Japanese quails ( $\mathrm{N}=180$ ) were randomly divided into six groups and each group was divided into three replicates $(\mathrm{N}=10$, each).

Group 1: (controls) was fed a commercially available diet, hereinafter called the basic diet, and was the principal component of the diet given to the birds in other groups.

Group 2: Basic diet plus $3 \mathrm{~g} \mathrm{TP} / \mathrm{kg}$.

Group 3: Basic diet plus $5 \mathrm{~g} \mathrm{TP} / \mathrm{kg}$.

Group 4: Basic diet plus 4 mg AF/kg.

Group 5: Basic diet plus $4 \mathrm{mg} \mathrm{AF}$ and $3 \mathrm{~g} \mathrm{TP} / \mathrm{kg}$.

Group 6: Basic diet plus $4 \mathrm{mg} \mathrm{AF}$ and $5 \mathrm{~g} \mathrm{TP} / \mathrm{kg}$.

The birds had free access to water and their specific diet, and were monitored daily for their health status. The birds were weighed on the first and last day of the study (day 23). At the conclusion of the study, 9 quails from each group were slaughtered and autopsied. Blood samples were collected from each bird and the liver was removed and weighed. This study was conducted in agreement with the standards of the Ethics Committee of the Razi Vaccine Production and Serum Research Institute in Karaj, Iran.

Serum levels of Liver Enzymes and Total Proteins: The serum samples were stored in a freezer at $-20^{\circ} \mathrm{C}$ for the determination of serum Alanine Aminotransferase (ALT), Aspartate Aminotransferase (AST) and Alkaline Phosphatase (ALP) enzymes and the total proteins. These tests were performed using an automated analyzer 
(Hitachi-917; Tokyo, Japan) and commercial kits (Pars Azmun Co., Tehran, Iran).

Evaluation of the Antioxidant Status of the Liver: The liver tissue from each bird was homogenized in 0.1 mo-

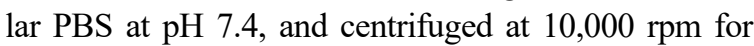
$15 \mathrm{~min}$ at $4^{\circ} \mathrm{C}$. The supernatant was collected and the levels of Total Antioxidant Capacity (TAC), Malondialdehyde (MDA) as indicator of lipid peroxidation, Superoxide Dismutase (SOD), and Catalase (CAT) were determined, using the respective commercial kits (Navand Salamat Co.; Iran).

Preparation and Evaluation of Histologic Sections: A part of each liver tissue was fixed in $10 \%$ formalin buffer, and was prepared for histological sectioning and staining with hematoxylin and eosin. Histopathological sections were examined under light microscopy (Olympus, Japan) and the lesions were graded according to the established method of Yavuz et al. [15].

Data Analysis: The data were tabulated in excel program and analyzed, using two-way ANOVA and tukey's multiple regression on SPSS V. 12. The maximum acceptable error was set at $\mathrm{P}<0.05$.

\section{Results}

The Body and Relative Liver Weights: In the AF group, body weight was significantly lower than that noted in the control group $(\mathrm{P}<0.05)$. Adding varying amounts of TP to AF-contaminated diet improved the birds' body and relative liver weights $(\mathrm{P}<0.05)$. The body and relative liver weights in the group that received AF plus $5 \mathrm{~g}$ $\mathrm{TP} / \mathrm{kg}$ of feed were not significantly different $(\mathrm{P}<0.05)$ from those of the control group (Table 1).

Serum Liver Enzymes and Total Proteins: Feeding the quails with AF-contaminated diets significantly increased the serum AST, ALT and ALP enzymes and decreased the total protein levels $(\mathrm{P}<0.05)$. Adding doses of TP to AF-contaminated diet improved the serum levels of liver enzymes and total proteins dosedependently $(\mathrm{P}<0.05)$. The addition of $5 \mathrm{~g} / \mathrm{kg}$ TP to the AF-contaminated feed had a higher protective effect on the modulation of serum factors than the $3 \mathrm{~g} / \mathrm{kg}$ TP. In the group that received $5 \mathrm{~g} / \mathrm{kg} \mathrm{TP}$, no significant difference was observed in the levels of ALT and ALP enzymes and total proteins, from those noted for the control group (Table 2).

Antioxidant Status of the Liver: The concentrations of SOD, CAT and TAC in AF group were significant- ly lower but the MDA concentration was significantly higher than those in the control group $(\mathrm{P}<0.05)$. Adding varying amounts of TP to AF-contaminated diet increased the levels of serum SOD, CAT and TAC $(\mathrm{P}<0.05)$. Adding $5 \mathrm{~g} \mathrm{TP} / \mathrm{kg}$ to AF-contaminated diet significantly reduced the MDA concentration. The level of TAC in the AF group that had $5 \mathrm{~g} / \mathrm{kg}$ TP in the feed was significantly higher than those detected for the other groups (Table 3 ).

Liver Histological Changes: Histopathologic lesions induced by adding $4 \mathrm{mg} / \mathrm{kg}$ AF to the birds' diet were liver fatty changes, periportal fibrosis, proliferation of the bile ducts, hyperemia, and leukocyte infiltration (Figures 1-4). In Group 6 (AF+5 g/kg TP in the feed), the severity of liver tissue lesions was not significantly different from those noted in the control group except for biliary duct proliferation and fatty changes that were more pronounced $(\mathrm{P}<0.05)$. In Group $5(\mathrm{AF}+3 \mathrm{~g} / \mathrm{kg}$ $\mathrm{TP}$ in the feed), the severity of periportal fibrosis was not significantly different from that in seen Group 4 $(\mathrm{P}<0.05)$. The severity of other lesions in Group 5 was higher than those seen in the control group but lower than that in Group 4 (Table 4).

\section{Discussion}

Changes in Body \& Liver Weights: The results showed that AF-contaminated feed reduced body weight and increased the relative liver weight in Japanese quails. The body weight loss and liver relative weight gain in AF fed Japanese quails have previously been reported by numerous studies in Iran [16-21]. Body weight loss is the major side effect of AF in poultry species [3]. These toxins can reduce body weight by disrupting the protein and fat synthesis, and reducing energy metabolism and proteins ingestion. They also impair liver function and the mechanisms of protein and fat utilization $[1,16,17]$. The relative liver weight is affected by AF toxicity faster than that in other body organs. The liver's relative weight

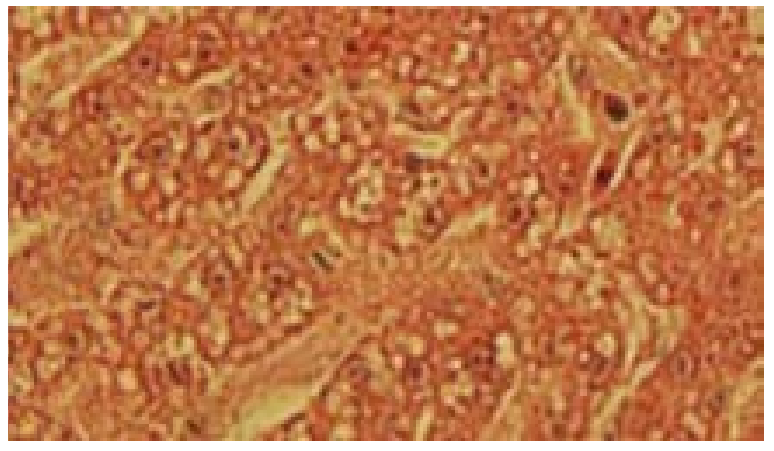

Figure 1. Liver fatty changes. H\&E, X 400. 
Table 1. Body andrelative liver weight among diets

\begin{tabular}{cccc}
\hline Groups & $\begin{array}{c}\text { Initial Body Weight } \\
\text { (g) }\end{array}$ & $\begin{array}{c}\text { Final Body Weight } \\
\text { (g) }\end{array}$ & $\begin{array}{c}\text { Relative Liver Weight } \\
\text { (\% of body weight) }\end{array}$ \\
\hline Control & $113.56 \pm 9^{\mathrm{a}}$ & $198.2 \pm 8.31^{\mathrm{c}}$ & $1.38 \pm 0.03^{\mathrm{a}}$ \\
\hline Control+3 mg/kg TP & $117.8 \pm 6.53^{\mathrm{a}}$ & $200.1 \pm 5.62^{\mathrm{c}}$ & $1.53 \pm 0.05^{\mathrm{a}}$ \\
\hline Control+5 mg/kg TP & $114.9 \pm 5.73^{\mathrm{a}}$ & $196.4 \pm 6.12^{\mathrm{c}}$ & $1.5 \pm 0.08^{\mathrm{a}}$ \\
\hline Control+4 mg/kg AF & $116.3 \pm 3.4^{\mathrm{a}}$ & $170.6 \pm 10.32^{\mathrm{a}}$ & $2 \pm 0.21^{\mathrm{c}}$ \\
\hline Control+3 mg/kg TP, +4 mg/kg of AF & $115.5 \pm 4.8^{\mathrm{a}}$ & $183.4 \pm 7.02^{\mathrm{b}}$ & $1.71 \pm 0.07^{\mathrm{b}}$ \\
\hline Control+5 mg/kg TP, $+4 \mathrm{mg} / \mathrm{kg} \mathrm{AF}$ & $116.5 \pm 4.21^{\mathrm{a}}$ & $210.3 \pm 8.4^{\mathrm{c}}$ & $1.42 \pm 0.06^{\mathrm{a}}$
\end{tabular}

Distinctive letters in the similar column demonstrate statistically significant difference $(\mathrm{P}<0.05)$.

Control: Basal diet; TP: Turmeric powder; AF: Aflatoxins. The order of significance were $\mathrm{a}<\mathrm{b}<\mathrm{c}$.

Table 2. Liver function among diets

\begin{tabular}{ccccc}
\hline Groups & ALT (U/L) & AST (U/L) & ALP (U/L) & Total Proteins (g/dl) \\
\hline Control & $31.56 \pm 2.4^{\mathrm{b}}$ & $16.45 \pm 1.2^{\mathrm{a}}$ & $965.07 \pm 22.3^{\mathrm{a}}$ & $3.98 \pm 0.04^{\mathrm{c}}$ \\
\hline Control+3 mg/kg TP & $33.66 \pm 4.3^{\mathrm{b}}$ & $17.03 \pm 0.63^{\mathrm{a}}$ & $1003.09 \pm 12.4^{\mathrm{a}}$ & $4.12 \pm 0.03^{\mathrm{c}}$ \\
\hline Control+5 mg/kg TP & $26.62 \pm 2.04^{\mathrm{a}}$ & $18.04 \pm 13^{\mathrm{a}}$ & $986.08 \pm 22.3^{\mathrm{a}}$ & $3.78 \pm 0.1^{\mathrm{c}}$ \\
\hline Control+4 mg/kg AF & $44.06 \pm 3.63^{\mathrm{d}}$ & $23.63 \pm 3.4^{\mathrm{c}}$ & $1468.9 \pm 43.2^{\mathrm{b}}$ & $3.06 \pm 0.15^{\mathrm{a}}$ \\
\hline Control+3 mg/kg TP, +4 mg/kg AF & $41.09 \pm 4.36^{\mathrm{c}}$ & $21.06 \pm 4.5^{\mathrm{b}}$ & $1398.62 \pm 52.3^{\mathrm{b}}$ & $3.59 \pm 0.3^{\mathrm{b}}$ \\
\hline Control+5 mg/kg TP, +4 mg/kg AF & $32.08 \pm 2.04^{\mathrm{b}}$ & $19.96 \pm 3.2^{\mathrm{b}}$ & $1.66 \pm 22.4^{\mathrm{a}}$ & $4.01 \pm 0.18^{\mathrm{c}}$ \\
\hline
\end{tabular}

Distinctive letters in the similar column demonstrate statistically significant difference $(\mathrm{P}<0.05)$.

Control: Basal diet; TP: Turmeric Powder; AF: Aflatoxins. The order of significance were $\mathrm{a}<\mathrm{b}<\mathrm{c}<\mathrm{d}$.

gain is due to impaired lipid synthesis, storage, and the accumulation of fat in the hepatocytes $[11,16,17]$.

Changes in Blood Parameters: The results of this study showed that the AF toxicity in Japanese quails increased the serum levels of liver enzymes, such as AST, ALT and ALP and reduced the total proteins concentration. Similar changes in liver functions have previously been reported in Japanese quails, exposed to oral AF by several studies [17, 21-23]. The serum levels of AST, ALT, and ALP enzymes are sensitive indicators of liver and biliary disorders. Increases in these enzymes occur due to damages to the liver hepatocytes, leading to their release into the blood stream [21-23].

Histological Changes: Our histopathological findings revealed that the liver lesions were induced in the birds after being fed AF-contaminated diet. Macroscopic and microscopic examinations of the liver are effective methods of studying AF toxicity. Fatty changes are known to be the most common histopathologic lesions caused by AF toxicity in birds' liver $[15,18,24]$. The fatty changes are probably due to the inhibition or impaired lipid synthesis. The proliferation of bile ducts, periportal fibrosis

Table 3. Liver antioxidant status among diets

\begin{tabular}{ccccc}
\hline Groups & $\begin{array}{c}\text { SOD } \\
\text { (U/mg protein) }\end{array}$ & $\begin{array}{c}\text { CAT } \\
\text { (nmol/mg protein) }\end{array}$ & $\begin{array}{c}\text { TAC } \\
\text { (nmol Fe+2/L) }\end{array}$ & $\begin{array}{c}\text { MDA } \\
\text { (nmol/mg protein) }\end{array}$ \\
\hline Control & $486.21 \pm 33.61^{\mathrm{b}}$ & $31.3 \pm 3.26^{\mathrm{c}}$ & $7.04 \pm 0.68^{\mathrm{b}}$ & $6.43 \pm 1.64^{\mathrm{b}}$ \\
\hline Control+3 mg/kg TP & $466.3 \pm 49.41^{\mathrm{b}}$ & $29.82 \pm 2.96^{\mathrm{c}}$ & $7.23 \pm 1.33^{\mathrm{b}}$ & $4.56 \pm 0.93^{\mathrm{a}}$ \\
\hline Control+5 mg/kg TP & $479.46 \pm 24.65^{\mathrm{b}}$ & $33.43 \pm 1.65^{\mathrm{c}}$ & $8.83 \pm 1.05^{\mathrm{c}}$ & $5.32 \pm 1.02^{\mathrm{a}}$ \\
\hline Control+4 mg/kg AF & $366.4 \pm 63.14^{\mathrm{a}}$ & $19.63 \pm 2.63^{\mathrm{a}}$ & $4.66 \pm 0.96^{\mathrm{a}}$ & $9.67 \pm 2.63^{\mathrm{d}}$ \\
\hline Control+3 mg/kg TP, +4 mg/kg AF & $458.78 \pm 36.96^{\mathrm{b}}$ & $26.45 \pm 4.13^{\mathrm{b}}$ & $8.01 \pm 0.87^{\mathrm{b}}$ & $8.98 \pm 0.58^{\mathrm{d}}$ \\
\hline Control+5 mg/kg TP, +4 mg/kg AF & $499.53 \pm 50.31^{\mathrm{b}}$ & $30.96 \pm 3.44^{\mathrm{c}}$ & $9.64 \pm 1.65^{\mathrm{d}}$ & $7.43 \pm 2.01^{\mathrm{c}}$ \\
\hline
\end{tabular}

Distinctive letters in the similar column demonstrate statistically significant difference $(P<0.0)$

Control: Basal diet; TP: Turmeric powder; AF: Aflatoxins. The order of significance were $\mathrm{a}<\mathrm{b}<\mathrm{c}<\mathrm{d}$. 
Table 4. Liver histological changes among diets

\begin{tabular}{|c|c|c|c|c|c|c|}
\hline Groups & Control & $\begin{array}{l}\text { Control+3 } \\
\mathrm{mg} / \mathrm{kg} \mathrm{TP}\end{array}$ & $\begin{array}{c}\text { Control+5 mg/ } \\
\text { kg TP }\end{array}$ & $\begin{array}{c}\text { Control+4 mg/ } \\
\text { kg AF }\end{array}$ & $\begin{array}{c}\text { Control+3 mg/kg TP, } \\
+4 \mathrm{mg} / \mathrm{kg} \mathrm{AF}\end{array}$ & $\begin{array}{c}\text { Control+5 mg/kg TP, } \\
+4 \mathrm{mg} / \mathrm{kg} \mathrm{AF}\end{array}$ \\
\hline Fatty change & $1 / 9^{a}$ & $1 / 9^{a}$ & $0 / 9^{a}$ & $9 / 9^{d}$ & $5 / 9^{c}$ & $3 / 9^{b}$ \\
\hline Mild & 1 & 1 & 0 & 1 & 3 & 2 \\
\hline Moderate & 0 & 0 & 0 & 3 & 1 & 1 \\
\hline Severe & 0 & 0 & 0 & 5 & 1 & 0 \\
\hline Periportal fibrosis & $0 / 9^{a}$ & $0 / 9^{a}$ & $0 / 9^{a}$ & $3 / 9^{b}$ & $2 / 9^{b}$ & $0 / 9^{a}$ \\
\hline Bile duct proliferation & $0 / 9^{a}$ & $0 / 9^{a}$ & $0 / 9^{a}$ & $5 / 9^{c}$ & $2 / 9^{b}$ & $2 / 9^{b}$ \\
\hline Hyperemia & $0 / 9^{a}$ & $0 / 9^{a}$ & $0 / 9^{a}$ & $6 / 9^{c}$ & $3 / 9^{b}$ & $1 / 9^{a}$ \\
\hline Leukocyte infiltration & $0 / 9^{a}$ & $0 / 9^{a}$ & $0 / 9^{a}$ & $7 / 9^{c}$ & $4 / 9^{b}$ & $1 / 9^{a}$ \\
\hline
\end{tabular}

Distinctive letters in the similar row demonstrate statistically significant difference $(\mathrm{P}<0.5)$

Control: Basal diet; TP: Turmeric powder; AF: Aflatoxins. The order of significance were $\mathrm{a}<\mathrm{b}<\mathrm{c}<\mathrm{d}$.

and leukocytosis are believed to be the regenerative and inflammatory responses of the liver, subsequent to $\mathrm{AF}$ toxicity $[8,15,24]$.

Antioxidant Impairments: The rise in the lipid peroxidation reflects the AF toxicity on liver tissue, and represents impaired activity and capacity of the antioxidant enzymes. The determination of MDA concentration, as the final product of lipid peroxidation in the liver, is a common method of assessing the oxidative stresses caused by $\operatorname{AF}[2,25]$. These toxins mainly accumulate in and metabolized by the liver. During the metabolic processing, AF species produce oxygen radicals, which cause oxidative stresses and damages to the hepatocytes' plasma membranes $[2,25,26]$. In this study, the rise in MDA concentration and decline in SOD, CAT and TAC levels in the liver of the quails exposed to oral AF are indicative of a decrease in the antioxidant status and

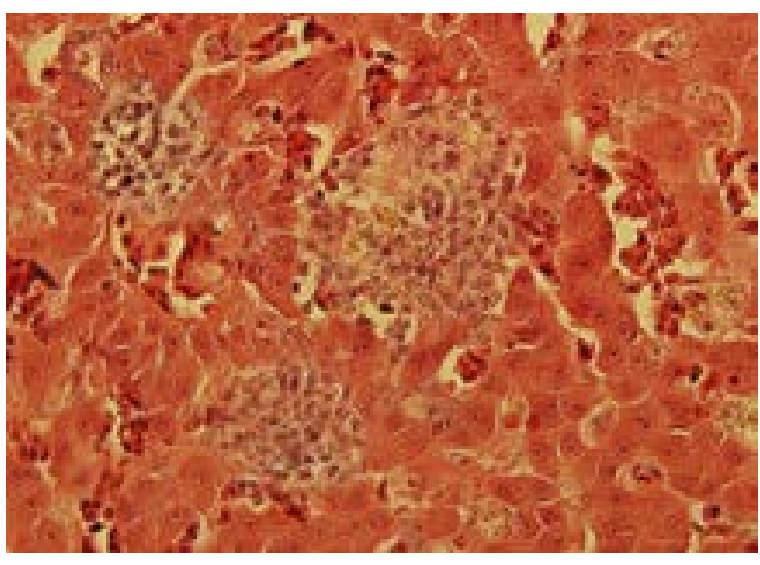

Figure 2. Liver leukocyte infiltration. H \& E, X 400. heightened oxidative stresses induced by AF, as confirmed previously by Migliorini et al. [26].

Protective Effects of Turmeric against AF: Our data indicated that using $3 \mathrm{~g} / \mathrm{kg}$ or $5 \mathrm{~g} / \mathrm{kg}$ of TP (containing 88.8 and $148 \mathrm{mg} / \mathrm{kg}$ TCM, respectively) in AF-contaminated diet, improved the liver antioxidant functions and reduced the lipid peroxidation. The TP also modulated the adverse effects of AF on changes in body and relative liver weights, serum liver enzymes and total proteins levels, and the liver histology. Increasing the amounts of TP to $5 \mathrm{~g} / \mathrm{kg}$ in the birds' diet that contained AF further improved the hepatic protection and reduced the adverse effects of the toxins on the organ.

The previous study [25] has reported that the use of $0.5 \% \mathrm{TP}$ containing $74 \mathrm{mg} / \mathrm{kg}$ TCM and $1 \mathrm{mg} / \mathrm{kg}$ AFB1 in birds' diet for 3 weeks relatively reduced the adverse effects of the toxin. Specifically, adding TP to the toxincontaminated diet increased the body weight, serum total proteins and antioxidant capacity of the liver, and de-

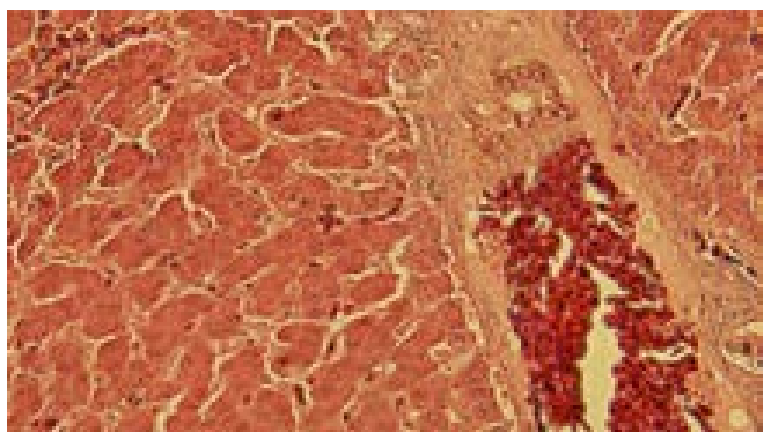

Figure 3. Liver periportal fibrosis and hyperemia. $\mathrm{H} \& \mathrm{E}, \mathrm{X} 400$. 


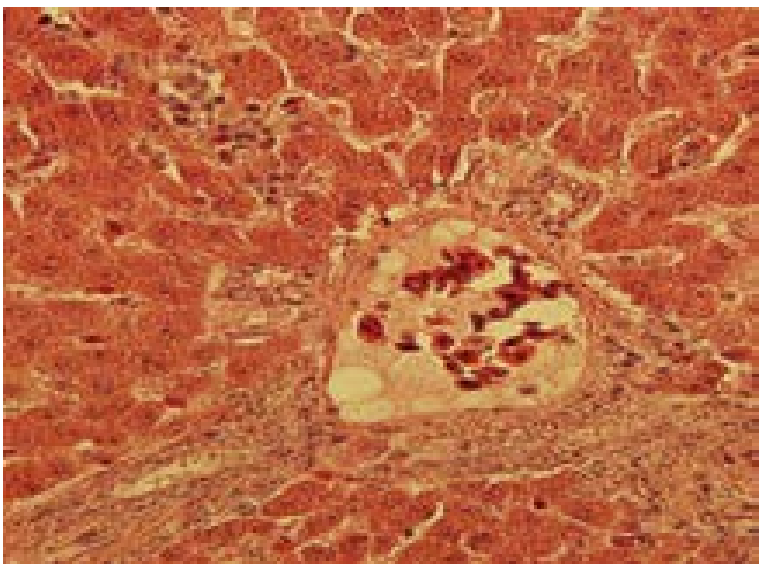

Figure 4. Liver bile duct proliferation. H \& E, X 400.

creased the lipid peroxidation, relative liver weight, and severity of histopathologic lesions in the liver compared to those seen in the group that was administered AFB1 only. In another study by Gowda et al. [11], the antioxidant properties of varying amounts of TP (containing $2.55 \%$ of TCM) were examined in broiler chickens exposed to $1 \mathrm{mg} / \mathrm{kg}$ AFB1. That study found that higher TCM concentration in birds' feed had greater antioxidant properties. In that study, $444 \mathrm{mg} / \mathrm{kg}$ TCM in the feed caused the least oxidative damages.

Adding $0.05 \%$ turmeric alcohol extract to the diet of broiler chickens infected with $3 \mathrm{mg} / \mathrm{kg} \mathrm{AF}$, reduced the serum ALT and AST levels, increased the total proteins and decreased histological changes in the liver [27]. Similarly, Zhang et al. [12] observed enhanced liver antioxidant capacity, reduced liver histopathologic lesions, modulated serum total proteins and AST and ALT enzymes by adding $150 \mathrm{mg} / \mathrm{kg}$ curcumin and $100 \mathrm{mg} /$ $\mathrm{kg}$ AFB1 to the diet of chickens. In a study by Muhammad et al. [28], adding $5 \mathrm{mg} / \mathrm{kg}$ AFB1 to varying doses of curcumin $(150,300$ or $400 \mathrm{mg} / \mathrm{kg})$ to the feed of broiler chickens, reduced the adverse effects of AF on the body weight, relative liver weight, and liver tissue lesions. The effect of curcumin was dose-dependent and the most significant effects were noted in this order: 400, 300 and $150 \mathrm{mg} / \mathrm{kg}$ curcumin.

More recently, Solis-Cruz et al. [9] have reported the effects of adding $0.2 \%$ curcumin to the diet of broiler chickens (1-21 day old) infected with $2 \mathrm{mg} / \mathrm{kg}$ AFB1 in the diet. This study confirmed that adding curcumin to the toxic diet improved the body weight, and decreased the liver weight relative to the whole body weight. Also, the extent of liver histopathologic lesions decreased, and the serum total proteins level increased.
The protective properties of turmeric against AF toxicity are believed to be due to its curcuminoid components. Turmeric roots contain three color analogs, called curcumin, methoxy curcumin and bis-methoxy curcumin, collectively called curcuminoids. Curcumin is the main and most potent component of curcuminoids. Curcumin is a non-flavonoid polyphenol with anti-inflammatory and antioxidant properties. Curcumin is one of the most potent free radical scavengers and inhibits the activity of the liver cytochrome P450 enzyme. This enzyme plays an important role in activating AF to the highly toxic form of epoxide. The increased activity of glutathione S-transferase, a detoxifying enzyme, leads to catalysis of the carcinogenic and cytotoxic constituents by conjugating them with glutathione $[9,12,27,28]$. It has antioxidant properties and protects the body against oxidative stresses. Lastly, TP decreases the expression of SOD and glutathione S-transferase genes, and inhibits the expression of cytochrome P450 and interleukin- 6 genes in the liver of broiler chickens upon exposure to $\mathrm{AF}$ [7, 28, 29].

Limitation of Study: The doses of turmeric powder used in the quails feed were limited to 3 and $5 \mathrm{mg} / \mathrm{kg}$. Also, the sampling and testing were performed only at the end of the study period. The possible effect of turmeric powder on residual toxins in the liver and inflammatory agents was not evaluated. Future studies on this topic should consider investigating a broader range of turmeric doses both at baseline and completion of experiments. They should also examine the potential antitoxic and anti-inflammatory effects on the liver and other organs.

\section{Conclusions}

This study confirmed that the addition of two doses of TP $(3 \mathrm{~g} / \mathrm{kg}$ and $5 \mathrm{~g} / \mathrm{kg}$ ) containing $2.96 \%$ curcuminoids to the Japanese quails feed, contaminated with $4 \mathrm{mg} / \mathrm{kg}$ $\mathrm{AF}$, improved the liver antioxidant capacity and consequently reduced the toxic effects of oral AF. Addition of greater amounts of TP $(5 \mathrm{~g} / \mathrm{kg})$ containing $148 \mathrm{mg} / \mathrm{kg}$ TCM had a greater protective property against the toxic effects of AF.

\section{Ethical Considerations}

\section{Compliance with ethical guidelines}

This study was conducted in agreement with the instructions of the Laboratory Animal Ethics Committee of the Razi Vaccine and Serum Research Institute. 
This study was funded by Sepid Parand Poultry Company and Yazd Agricultural and Natural Resources Research and Education Center.

\section{Author's contributions}

Conceptualization and resources: Omid Karimi; Methodology and investigation: all authors; Writing original draft: Omid Karimi, Mohammad Reza Mofidi; Funding acquisition: Omid Karimi, Mohammad Sadegh Saeidabadi.

\section{Conflict of interest}

The authors declared no conflict of interest.

\section{Acknowledgements}

The authors would like to thank the staffs of Animal Sciences Research Department of Yazd Agricultural and Natural Resources Research and Education Center.

\section{References}

[1] Mahmood S, Younus M, Aslam A, Anjum AA. Toxicological effects of aflatoxin B1 on growth performance, humeral immune response and blood profile of Japanese quail. J Anim Plant Sci. 2017; 27(3):833-40. http://www.thejaps.org.pk/ docs/v-27-03/19.pdf

[2] Marin DE, Taranu I. Overview on aflatoxin and oxidative stress. Toxin Rev. 2012; 31(3-4):32-43. [DOI:10.3109/1556954 3.2012.730092]

[3] Murugesan GR, Ledoux DR, Naehrer K, Berthiller F, Applegate TJ, Grenier B, et al. Prevalence and effect of mycotoxin on poultry health and performance, and recent development in mycotoxin counteracting strartegies. Poult Sci. 2015 94(6):1298-315. [DOI:10.3382/ps/pev075] [PMID] [PMCID]

[4] Rawal R, Kim JE, Coulombe R Jr. Aflatoxin B1 in poultry: Toxicology, metabolism and prevention. Res Vet Sci. 2010; 89(3):325-31. [DOI:10.1016/j.rvsc.2010.04.011] [PMID]

[5] Monson MS, Coulombe RA, Reed KM. Aflatoxicosis: Lessons from toxicology and responses to aflatoxin B1 in poultry. Agriculture. 2015; 5(3):742-77. [DOI:10.3390/agriculture5030742]

[6] Diaz GJ, Murcia HW, Cepeda SM. Cytochrome P450 enzymes involves in the metabolism of aflatoxin B1 in chicken and quails. Poult Sci. 2010; 89(11):2461-9. [DOI:10.3382/ ps.2010-00864] [PMID]

[7] Yarru LP, Settivari RS, Gowda NKS, Antoniou E, Ledoux DR, Rottinghaus GE. Effect of turmeric (Curcuma longa) on the expression of hepatic genes associated with biotransformation, antioxidant, and immune system in broiler chicks fed aflatoxin. Poult Sci. 2009; 88(12):2620-7. [DOI:10.3382/ ps.2009-00204] [PMID]

[8] Guil-Guerrero JL, Ramos L, Zúñiga Paredes JC, Carlosama-Yépez M, Moreno C, Ruales P. Effect of turmeric rhizome powder and curcumin on poultry production. A review. J Anim Feed Sci. 2017; 26(4):293-302. [DOI:10.22358/ jafs/78511/2017]

[9] Solis-Cruz B, Hernandes-Patlan D, Petrone VM, Pontin KP, Latorre JD, Beyssac E, et al. Evaluation of cellulosic Polymers and curcumin to reduce aflatoxin B1 toxic effects on performance biochemical, and immunological parameters of broiler chickens. Toxins. 2019; 11(2):121. [DOI:10.3390/toxins11020121] [PMID] [PMCID]

[10] Jayaprakasha GK, Rao LJM, Sakariah KK. Improved HPLC method for determination of curcumin, demethoxycurcumin, and bis-demethoxycurcumin. J Agric Food Chem. 2002; 50(13):3668-72. [DOI:10.1021/jf025506a] [PMID]

[11] Gowda NKS, Ledoux DR, Rottinghaus GE, Bermudez AJ Chen YC. Antioxidant efficacy of curcuminoids from turmeric (Curcuma longa L.) powder in broiler chickens fed diets containing aflatoxin B1. Br J Nutr. 2009; 102(11):1629-34. [DOI:10.1017/S0007114509990869] [PMID]

[12] Zhang NY, Qi M, Zhao L, Zhu MK, Guo J, Liu J, et al. Curcumin prevents aflatoxin B1 hepatoxicity by inhibition of cytochrome P450 isozymes in chick liver. Toxins. 2016; 8(11):327. [DOI:10.3390/toxins9010001] [PMID] [PMCID]

[13] Shotwell OL, Hesseltine CW, Stubblefield RD, Sorenson WG Production of aflatoxin on rice. Appl Microbiol. 1966; 14(3):425 8. [DOI:10.1128/AEM.14.3.425-428.1966] [PMID] [PMCID]

[14] Institute of Standards and Industrial Research of Iran. Food and feed stuffs - Determination of aflatoxins B \& G by HPLC method, using immunoaffinity column clean up. Test Method. $1^{\text {st }}$ ed. ISIRI, 6872; 2011.

[15] Yavuz O, Özdemir Ö, Ortatati M, Atalay B, Hatipoglu F, Terzi F. The preventive effects of different doses of Glucomannan on experimental aflatoxicosis in Japanese quails. Braz J Poult Sci. 2017; 19(3):409-16. [DOI:10.1590/1806-9061-2016-0349]

[16] Aftabi M, Bagherzadeh Kasmani F, Jalilvand Gh, Mehri M, Karimi Torshizi MA. [Effect of protexin probiotics supplementation to aflatoxin contaminated diet on performance of Japanese quail (Persian)]. J Anim Prod. 2005; 17(1):131-40 https://www.researchgate.net/publication/288447428

[17] Bagherzadeh Kasmani F, Mehri M. Effects of multi-strain probiotics against aflatoxicosis in growing Japanese quails. Livest Sci. 2015; 177:110-6. [DOI:10.1016/j.livsci.2015.04.018]

[18] Arak H, Karimi Torshizi MA, Rahimi Sh. [Study on the effect of savory (Satureja khuzestanica) essential oil and polysorb toxin-binder against experimental aflatoxicosis in Japanese quail (Persian)]. J Vet Clin Pathol. 2013; 7(27):249-59. https://www.researchgate.net/publication/288181452

[19] Manafi M, Arak H, Hedayati M. [The effect of inclusion of various levels of aflatoxin B1 on performance, relative weights of internal organs and blood parameters of Japanese quails during the growing period (1-28 days) (Persian)]. Anim Sci J. 2015; 28(107):33-40. [DOI:10.22092/ ASJ.2015.102335]

[20] Gooran A, Shivazad M, Rezaeian M. [Efficacy of aqueous extract of thymus daenensis to ameliorate the adverse effects 
of aflatoxin in Japanese quails (Persian)]. Res Anim Prod. 2017; 18(15):25-32. [DOI:10.29252/rap.8.15.25]

[21] Khaleghipour B, Khosravinia H, Toghiyani M, Azarfar A Effects of silymarin on productive performance, liver function and serum biochemical profile in broiler Japanese quail challenged with dietary aflatoxins. Italian J Anim Sci. 2019; 18(1):564-73. [DOI:10.1080/1828051X.2018.1548310]

[22] Manafi M. Toxicity of aflatoxin B1 on laying Japanese quails (Coturnix coturnix japonica). J Appl Anim Res. 2018; 46(1):953-9. [DOI:10.1080/09712119.2018.1436550]

[23] Sakamato MI, Murakami AE, Fernandes AM, OspinaRojas IC, Nunes KC, Hirata AK. Performance and serum biochemical profile of Japanese quail supplemented with silymarin and contaminated with aflatoxin B1. Poult Sci. 2018; 97(1):159-66. [DOI:10.3382/ps/pex277] [PMID]

[24] Magnoli AP, Monge MP, Nazar FN, Magnoli CE, Cavaglieri LR, Bagnis G, et al. Combined effects of aflatoxin B1 and corticosterone treatment on selected performance indices and liver histopathology in Japanese quails. Poult Sci. 2012; 91(2):354-61. [DOI:10.3382/ps.2011-01763] [PMID]

[25] Gowda NKS, Ledoux DR, Rottinghaus GE, Bermudez AJ Chen YC. Efficacy of turmeric (Curcuma longa), containing a known level of curcumin, and a hydrated sodium calcium aluminosilicate to ameliorate the adverse effects of aflatoxin in broiler chicks. Poult Sci. 2008; 87(6):1125-30. [DOI:10.3382/ ps.2007-00313] [PMID]

[26] Migliorini MJ, da Silva AS, Santurio JM, Bottari NB, Gebert $\mathrm{RR}$, Reis JH, et al. The protective effects of an adsorbent against oxidative stress in quails fed aflatoxin- contaminated diet. Acta Sci Vet. 2017; 45:1473. [DOI:10.22456/1679-9216.80468]

[27] Gholami-Ahangaran M, Rangsaz N, Azizi S. Evaluation of turmeric (Curcuma longa) effect on biochemical and pathological parameters of liver and kidney in chicken aflatoxicosis. Pharm Biol. 2016; 54(5):780-7. [DOI:10.3109/13880209.20 15.1080731] [PMID]

[28] Muhammad I, Sun X, Wang H, Li W, Wang X, Cheng P, et al. Curcumin successfully inhibited the computationally identified CYP2A6 enzyme-mediated bioactivation of aflatoxin B1 in arbor acres broiler. Front Pharmacol. 2017; 8:143. [DOI:10.3389/fphar.2017.00143] [PMID] [PMCID]

[29] Limaye A, Yu RC, Chou CC, Liu JR, Cheng KC. Protective and detoxifying effects conferred by dietary selenium and curcumin against AFB1-mediated toxicity in livestock: A review. Toxins. 2018; 10(1):25. [DOI:10.3390/toxins10010025] [PMID] [PMCID] 